\title{
Auxological and endocrinological features in internationally adopted children
}

\author{
Stefano Stagi ${ }^{1 *}$ (D, Valeria Papacciuoli ${ }^{1}$, Djibril Boiro², Chiara Maggioli ${ }^{1}$, Niane Ndeye Ndambao ${ }^{2}$, Stefania Losi $^{1}$, \\ Elena Chiappini', Sonia Toni ${ }^{1}$ and Ousmane Ndiaye ${ }^{2}$
}

\begin{abstract}
In internationally adopted children disorders of linear growth, puberty development, thyroid function, and bone metabolism are frequently reported. It is important that these children receive careful auxological and endocrinological evaluations and follow-up.

Pediatricians and other healthcare providers should be aware that auxological and endocrinological problems are common in newly arrived international adoptees.
\end{abstract}

Keywords: Adopted children, Growth, Growth chart, Puberty, Precocious puberty, Bone age, Congenital hypothyroidism, lodine

\section{Key notes}

- Children who are adopted internationally should be assessed for linear growth, puberty development, thyroid function, and bone metabolism disorders.

- A close auxological and endocrinological evaluation with follow-up is mandatory in these children.

- Pediatricians and other healthcare providers should be aware that auxological and endocrinological problems are common in newly arrived international adoptees.

\section{Introduction}

Approximately 260,000 international adoptions take place worldwide each year [1]. The countries which welcome the highest numbers of children are the USA, France, Spain and Italy where nearly 2000 international adoptees arrive every year [2].

In recent years there have been important changes regarding the volume of adoptions, the countries involved

\footnotetext{
* Correspondence: stefano.stagi@yahoo.it

'Health Sciences Department, University of Florence, Anna Meyer Children's University Hospital, Viale Pieraccini 24, 50139 Florence, Italy

Full list of author information is available at the end of the article
}

and the characteristics of families deemed suitable to adopt [1]. The living conditions of children in their countries of origin are very variable. Most live in orphanages, where they may experience emotional abandonment, physical neglect and malnutrition and be exposed to infectious diseases (ex. tuberculosis and parasitic infections) [3, 4]. The history of these children may be positive for pre- and perinatal complications, such as exposure to drugs and alcohol during gestation, absence of perinatal care, low birth weight, and prematurity $[3,4]$. Often a combination of these factors leads to auxological or endocrinological problems and it is important to bear this in mind when the children arrive in their country of adoption [5]. Medical problems are reported in more than $40 \%$ cases [6]. Early pubertal development, chronic malnutrition and low weight are frequently reported conditions $[7,8]$. Initial assessments are often complicated by the absence of up to date growth charts for specific countries and the lack of neonatal screening programs or paediatric care in the countries of origin.

In this review we evaluate the main auxological and endocrinological problems encountered in international adoptees in order to shed light on those that are most 
frequent. We hope to provide some useful suggestions for looking after these children.

\section{Growth and growth disorders}

The assessment of growth is the most useful tool for defining the health of a child. By monitoring growth, we can evaluate a child's nutritional status. The Tanner scale allows us to determine whether pubertal development is at an appropriate stage and diagnose any growth disorders with a non-nutritional basis [9].

Internationally adopted children may present growth suppression as a consequence of institutional care in their countries of origin [10]. Factors which negatively impact growth include neglect and chronic malnutrition due to a lack of sufficient personnel to meet the needs of the children [11]. Moreover, parasite infections can result in iron deficiency and a reduction in the absorption of micro- and macronutrients $[10,12,13]$.

Neglect during early childhood seems to slow growth rates in height and weight for children, suggesting that early childhood is a critical period for a child's growth in later life [14]. In fact, institutionalized children often experience emotional and nutritional deprivation that precludes adequate environmental stimulation and nutrition, essential elements for normal growth [15]; in these subjects, growth delay has been termed psychosocial dwarfism. Moreover, stress from psychological harassment has been shown to lead to abnormal circadian rhythms and suppression of growth hormone release [16].

Post-placement recovery has been widely documented. In fact, most adoptees demonstrate excellent catch-up growth within six months of adoption. If growth failure persists after 6 months of appropriate caloric intake, nutrition-independent causes should be considered [17]. However, little is known about how long children take to recover normal growth patterns, especially if we consider that pre-adoptive experiences are diverse [18]. Generally, following adoption, children undergo a variable catch-up growth, in part due to normalization of the growth hormone system [19].

However, some data suggest that the length of this catch-up period may depend on the children's countries of origin and that there may be significant auxological variations. For example, children adopted from Ethiopia or Eritrea often reside for relatively long periods of time with relatives prior to institutionalization and exhibit few behavioural problems on arrival. In general, they have good growth, and less severe developmental delays [20]. It can be difficult to accurately establish the child's age which may to lead to mistakes, for example a misdiagnosis of precocious puberty and inappropriate pharmacological treatments. Unfortunately, there are no accurate tests for determining age. Malnutrition and deprivation may affect assessments of bone age, whereas the onset of puberty and improved nutrition may increase bone density.

Children adopted from Romania and other Eastern European countries have often been placed in institutions with very low quality of care [11] and children adopted from Poland and the former Soviet Union have a high risk of presenting a fetal alcohol spectrum disorder (FASD) which may go undiagnosed [21]. Adoptive parents and professionals need to be aware of the potential consequences of prenatal exposure to alcohol [21, 22] [Table 1]. Guatemalan and Chinese adoptees display similar overall patterns of growth and developmental delays as seen in other groups of internationally adopted children, although not as severe [23, 24].

As well as presenting stunted growth, malnourished children often present retarded bone maturity comparable to children affected by diseases such as coeliac disease, inflammatory bowel disease and hormonal deficiency. If puberty is delayed and/or growth continues into the early or mid-twenties, then an acceptable final adult height can be achieved. However, an individual's maximum height may also be limited by genetic imprinting in very early development. This may be the case where full catch-up appears to have taken place but is followed by an advanced puberty and early cessation of growth [25-27].

One study showed that children with rickets on arrival did not achieve the recovery levels of non-stunted children, suggesting that deficiencies in early life can only be partially recovered. Such auxological dynamics can also be associated with early pubertal development which can shorten the period of growth and therefore contribute to a reduced adult height. Mechanisms underlying early pubertal development and optimal management of nutritional rehabilitation after chronic malnutrition need to be clarified [8]. One study, involving 107 girls, evaluated the model of growth and final height in relation to nutritional status at arrival and at menarche. The data suggest that most of the girls recovered some of their growth in height and about half of them in weight. The presence of faster recovery growth and a later arrival age were associated with an early menarche. Recovery growth was, however, incomplete, suggesting that linear growth and final height were influenced by pre-adoption nutritional conditions, as well as by the degree and timing of subsequent recovery growth and puberty times [27].

The development and growth of internationally adopted children in the countries of their adoptive families [28] should be carefully monitored. Unfortunately, many country-specific growth charts are out-of-date, were drawn up using small sample sizes and may be relevant to ethnic groups other than that of the adopted child. There was a step forward in 2006 when the World Health Organization released new international charts 
Table 1 Criteria for the Diagnosis of Fetal alcohol spectrum disorders (FASD)

\begin{tabular}{|c|c|}
\hline Terminology & Diagnostic Features \\
\hline Fetal alcohol syndrome (FAS) & $\begin{array}{l}\text { All of the following criteria: } \\
\text { - three facial abnormalities (ie, smooth philtrum, thin vermillion border, and small palpebral } \\
\text { fissures). Midface hypoplasia, micrognathia, microcephaly or epicanthal folds may also be } \\
\text { observed; } \\
\text { - growth deficiency (height and/or weight } \leq 10 \text { th percentile at any age) } \\
\text { - structural, neurologic, or functional central nervous system (CNS) abnormalities } \\
\text { - prenatal exposure to alcohol (PAE) }\end{array}$ \\
\hline Partial FAS & $\begin{array}{l}\text { - some (but not all of the physical features of FAS) (see above) } \\
\text { - CNS damage (structural, neurologic, and/or functional impairment) } \\
\text { - confirmed prenatal exposure to alcohol }\end{array}$ \\
\hline Alcohol-related birth defects & $\begin{array}{l}\text { Individuals who do not have the facial characteristics of full FAS } \\
\text { - Significant birth defects affecting the heart, eyes, kidneys, and/or bones resulting from PAE } \\
\text { - Hearing may also be affected } \\
\text { - Usually do not meet criteria for CNS structural or functional abnormalities } \\
\text { - Confirmed prenatal exposure to alcohol }\end{array}$ \\
\hline Alcohol-related neurodevelopmental disorder & $\begin{array}{l}\text { Cluster of symptoms that may include intellectual disabilities as well as challenges with } \\
\text { behaviour and learning resulting from PAE } \\
\text { May also have a CNS anomaly } \\
\text { Often perform poorly in school and have difficulties with maths, memory, attention, judgment, } \\
\text { and impulse control } \\
\text { Confirmed prenatal exposure to alcohol }\end{array}$ \\
\hline $\begin{array}{l}\text { Neurobehavioral disorder associated with prenatal } \\
\text { alcohol exposure (ND-PAE) }\end{array}$ & $\begin{array}{l}\text { Impairment of neurocognition, self-regulation, and adaptive functioning } \\
\text { - Combines deficits in these } 3 \text { areas in conjunction with evidence of PAE, childhood onset of } \\
\text { symptoms, and significant distress or impairment in social, academic, occupational, or other } \\
\text { important areas } \\
\text { - Confirmed prenatal exposure to alcohol }\end{array}$ \\
\hline
\end{tabular}

CNS, central nervous system. ${ }^{a}$ Not necessary if the first 3 features are present. Adapted by [25].

based on many thousands of children from Brazil, Ghana, India, Norway, Oman and the USA [29]. These Growth Standards have been adopted by many countries as a standard measure for assessing the growth of infants and young children $[30,31]$. This is important because children from some ethnic groups could paradoxically present an excessive or reduced stature compared to their peers in their countries of arrival that is nonpathological and should not be treated as a medical condition.

Since pathological conditions may radically alter bodily growth, accurately estimating a child's age is important in the care of adopted children, even in cases in which a child's age appears undisputed [32]. The use of specific growth curves and reliable skeletal age detection techniques, together with a correct auxological evaluation, can bring to light an incorrect age and thus avoid social and psychological problems linked to an inappropriate collocation in school [32].

Finally, there has been discussion about the possible role of organic pollutants on pre-adoption growth failure. The little available data seems show that exposure to endocrine disruptors, air pollution, second-hand smoke, and the mother's lifestyle during pregnancy affect children's growth and development [33, 34]. Some studies have also suggested that endocrine-disrupting chemicals can affect the catch-up growth and early puberty of children who were born and exposed to such chemicals in developing countries and who subsequently moved to a developed country [33]. For example, a retrospective study involving 145 patients in Belgium who were treated for precocious puberty, suggested that in immigrant children (adopted and non-adopted), exposure to oestrogenic endocrine disrupters may have contributed to early puberty [33].

There is evidence that physiological adaptations to deprived environments in early childhood can increase the risk of obesity, early onset puberty in girls and metabolic syndrome and cardiovascular disease, particularly if there is a shift over time from resource-poor to resource-rich environments [35]. Clinically, there is concern that PI (post-institutionalized) children with rapid catch-up growth may be at a higher risk for obesity, early onset puberty in girls, and, in adulthood, metabolic syndrome [35].

Studies of children in low and middle income (LAMI) countries show that early postnatal catch-up growth is associated with obesity and a high risk of developing metabolic syndrome later in life. The rapid catch-up growth observed in internationally adopted children could be a risk factor for later obesity and early onset puberty, both of which are risk factors for cardiovascular diseases, type-2 diabetes, and musculoskeletal disorders [35]. However, one study which aimed to test the hypothesis that a shift from psychosocial and physical deprivation to highly resourced homes would increase 
the risk of obesity in boys and girls, suggested that stress and growth stunting early in life do not necessarily result in early onset puberty (for girls) and obesity [35]. It is possible that the early timing of removal from adversity or the context of the adoptees' upbringing in highly resourced homes with highly educated parents may alter and perhaps buffer children from long-term impacts on BMI and early pubertal development. Of course, it is critical to follow the subsequent waves of data collection on this project to understand growth curves both of body fat and pubertal stage as the PI youths progress through adolescence [35].

\section{Puberty and pubertal disorders}

The association between precocious puberty and international adoption was first described by Swedish authors in 1981 [36] in a case series of 7 girls adopted from India and Bangladesh and is well documented [37, 38]. Various studies in different countries have demonstrated the correlation $[39,40]$, although a recent report by Hayes et al. did not confirm the link in a population of 814 Chinese girls adopted in the USA and Canada [40].

There seem to be several causes for this association which are not fully understood. It is speculated that improved nutritional and socio-economic conditions lead to a period of catch up growth and the following early onset of puberty [37]. A similar phenomenon has been observed in the general population, where historical trends demonstrate that earlier puberty is a result of socio-economic development [41].

Some authors have postulated that early puberty follows the period of catch-up growth only after fetal or fetalpostnatal undernutrition, but not after postnatal undernutrition [41]. This is similar to what is described in many studies about IUGR and SGA children [42, 43].

Moreover, early puberty is also observed in nondeprived migrating children [42]. In defining early puberty, it is also important to establish the median age at menarche in a child's country of origin and in cases where the age of a child cannot be accurately established it may be impossible to determine whether puberty is early [43].

The current treatment of idiopathic precocious puberty is with gonadotrophin-releasing hormone $(\mathrm{GnRH})$ agonists [37]. Many studies have been published about the indications, goals and effects of this therapy but only a few concentrate on adopted children [37, 44, 45]. The main goals of therapy are auxological and psychological. For adopted children, it may often be impossible to establish a genetic target. Reference growth charts for the child's native countries should be used. Predicting adult height in adopted children is difficult because it is difficult to know the long-term effects of early life adversity and malnutrition [44]. In general, responses to GnRH agonists in adopted children are similar to those of the general population with idiopathic precocious puberty [37]. Some reports evaluated the addition of $\mathrm{GH}$ to GnRH agonists with contrasting results [41, 44-46]. Mul et al. concluded that the association resulted in limited further increases in height gains [47].

\section{Thyroid disorders}

Thyroid function is critical for the development of the central nervous system in the fetus and in children and iodine is an essential component of thyroid hormones [48]. 28.9\% of the world's population has an iodine deficiency [49] [Table 2]. In 2013, school-aged children in nearly 30 countries were deemed iodine-deficient, in 9 moderately deficient and in 21 mildly deficient [50]. Congenital hypothyroidism $(\mathrm{CH})$ is the one of the most common preventable causes of mental retardation and the condition is included in programs of neonatal screening worldwide [51].

Unfortunately, the spread of neonatal screening as well as campaigns for reducing iodine deficiency have obtained variable results and large areas of the planet are still not fully covered [Table 2]. It is therefore important to consider iodine deficiencies in adopted children.

Severe iodine deficiency may cause hypothyroidism that results in impaired somatic growth and motor development [51]. Overt cretinism is the most extreme form of mental retardation due to this deficiency [50].

In neonates of the Democratic Republic of the Congo, a $10 \%$ rate of biochemical hypothyroidism has been found [52]. This hypothyroidism persists into infancy and childhood if the deficiency is not corrected, and results in retarded physical and mental development [53]. In the most severely iodine deficient environments of Northern India, the incidence of neonatal hypothyroidism was 75 to 115 per thousand births [54]. By contrast in Delhi, where only mild iodine deficiency is present, the incidence drops to 6 per thousand [55].

Most neonates with $\mathrm{CH}$ have a normal appearance and no detectable physical signs at birth; hypothyroidism in this period is often overlooked and delayed diagnosis may to lead to mental retardation [51]. Pilot $\mathrm{CH}$ screening programs began in 1972 and new born screening is now routine in the developed world, but many countries still do not have effective screening programs [51]. Adoptees from countries were screening programs are not established should be screened for $\mathrm{CH}$ and if required undergo thyroid function examinations. The screening of iodine deficiency is also important and knowledge of iodine deficiency areas in the world is important for an early determination of this problem.

\section{Bone metabolism and density}

Vitamin D deficiency is not only reported in cold or temperate countries [56], but also in countries with adequate sunshine [57]. Deficient calcium intake is also important [56, 57]. Adolescents are more prone to 
Table 2 The extent of congenital hypothyroidism screening worldwide

\begin{tabular}{|c|c|c|c|}
\hline \multicolumn{4}{|c|}{ Nord America } \\
\hline \multicolumn{4}{|c|}{ Full coverage of the population. } \\
\hline \multicolumn{4}{|c|}{ Latin America } \\
\hline \multicolumn{4}{|c|}{ Full coverage of the population with the exception of: } \\
\hline $\begin{array}{l}\text { Dominican } \\
\text { Republic }\end{array}$ & \multicolumn{3}{|c|}{$\begin{array}{l}\text { Offered in the private } \\
\text { sector }\end{array}$} \\
\hline El Salvador & \multicolumn{3}{|c|}{ Not available to all } \\
\hline Haiti & \multicolumn{3}{|l|}{-} \\
\hline Honduras & \multicolumn{3}{|l|}{-} \\
\hline \multicolumn{4}{|l|}{ Europe } \\
\hline \multicolumn{4}{|c|}{ Full coverage of the population with the exception of: } \\
\hline Albania & \multicolumn{3}{|l|}{$\begin{array}{l}\text { Beginning } \\
\text { implementation }\end{array}$} \\
\hline Azerbaijan & \multicolumn{3}{|l|}{ No data } \\
\hline Kosovo & \multicolumn{3}{|l|}{$\begin{array}{l}\text { Beginning } \\
\text { implementation }\end{array}$} \\
\hline Moldova & \multicolumn{3}{|l|}{-} \\
\hline \multicolumn{4}{|c|}{ Middle East and North Africa } \\
\hline \multicolumn{4}{|c|}{ Available data about the coverage of the population: } \\
\hline Algeria & Private efforts & Saudi Arabia & $>90 \%$ \\
\hline Bahrain & $>90 \%$ & Somalia & - \\
\hline Egypt & $>90 \%$ & Palestine & $>90 \%$ \\
\hline Iran & $85 \%$ & Sudan & - \\
\hline Iraq & $20 \%$ & Syrian & - \\
\hline Israel & $>90 \%$ & Tunisia & \\
\hline Jordan & $>90 \%$ & $\begin{array}{l}\text { United Arab } \\
\text { Emirates }\end{array}$ & $100 \%$ \\
\hline Kuwait & High coverage & Yemen & - \\
\hline Lebanon & $50 \%$ & Lybian & - \\
\hline Oman & $>90 \%$ & Morocco & Starting \\
\hline Qatar & $100 \%$ & & \\
\hline \multicolumn{4}{|l|}{ Asia Pacific } \\
\hline \multicolumn{4}{|c|}{ Full coverage of the population with the exception of: } \\
\hline Cambodia & \multicolumn{3}{|c|}{ Pilot testing or not full population testing } \\
\hline India & \multicolumn{3}{|c|}{ Pilot testing or not full population testing } \\
\hline Indonesia & \multicolumn{3}{|c|}{ Pilot testing or not full population testing } \\
\hline North Korea & \multicolumn{3}{|c|}{ Not available data } \\
\hline Laos & \multicolumn{3}{|c|}{ Pilot testing or not full population testing } \\
\hline Mongolia & \multicolumn{3}{|c|}{ Pilot testing or not full population testing } \\
\hline Myanmar & \multicolumn{3}{|c|}{ Pilot testing or not full population testing } \\
\hline Nepal & \multicolumn{3}{|c|}{ Pilot testing or not full population testing } \\
\hline Pakistan & \multicolumn{3}{|c|}{ Pilot testing or not full population testing } \\
\hline Sri Lanka & Pilot testing or & opulation testing & \\
\hline Vietnam & Pilot testing or & opulation testing & \\
\hline Modified by 5 & & & \\
\hline
\end{tabular}

vitamin $\mathrm{D}$ deficiency because of the greater mineral demands of their growing skeletons [58]. Nutritional rickets in adolescents in temperate and tropical countries has been reported [59], even if the signs and symptoms may be subtle and nonspecific [60].

Vitamin D insufficiency is common in internationally adopted children, from all ethnic groups, although rickets has been cited only rarely in articles about the health problems of children adopted internationally during the 1980s and 1990s [60-62]. In children adopted from Romania, many of whom lived in orphanages for years before adoption, rickets has been mentioned only seldomly [63]. Early case reports of children with vitamin D deficiency rickets adopted from the former Soviet Union illustrate the physical findings that may be observed, some of which may be atypical [62]. It is reported that these children had limited sunlight exposure and no vitamin supplementation [62]. Many of the rachitic features typically resolve over 12-24 months with vitamin $\mathrm{D}$ and calcium supplementation. Vitamin D abnormalities are found in 46.7\% of adopted children [64]; this deficit may be due to several factors, such as a low intake of calcium and vitamin D, environmental causes such as a lack of exposure to ultraviolet rays and ethnical racial characteristics such as the amount of melanin in the skin $[65,66]$. Additionally, many children have inadequate caloric and/or vitamin $\mathrm{D}$ intake prior to adoption. A low body mass index and longer time spent in an institution (correlated to reduced time outdoors) are associated with vitamin D deficiency and insufficiency [67]. The significance of vitamin D insufficiency on bone development during the typical catch-up growth following international adoption needs to be determined [67].

Because children generally experience rapid catch-up growth in the first year with their adoptive families, they may need larger amounts of dietary or supplemental iron and other nutrients than other children of the same age. An evaluation of serum $25(\mathrm{OH}) \mathrm{D}$ levels after adoption can allow the prompt introduction of vitamin $\mathrm{D}$ supplementation/treatment if needed [68]. In internationally adopted children a specific therapy as well as prophylaxis for hypovitaminosis $\mathrm{D}$ should also be considered.Salerno and al have suggested that there is a widespread global vitamin D insufficiency and that higher doses than currently recommended are needed to reach country specific "desirable" levels. The early introduction of vitamin D supplementation/treatment may be particularly important in older children with dark skin who arrive in Italy during winter and spring [69].

\section{Hypothalamic-pituitary-adrenal (HPA) axis}

Development of the hypothalamic-pituitary-adrenal axis is affected by genetics and pre- and postnatal environmental factors. A lot of studies report significant 
variations from normal functioning of the HPA caused by adversity early in life or even prior to conception [70]. These effects can lead to increased risks for mood and health disorders [71].

Studies about early life adversity (ELA) and HPA functioning provide discordant results [72]. Some studies identify hyper- and others hypo- or normal functioning of the axis, but the outcome measure is different varying from evaluation of basal to stress reactivity of the HPA axis. Subjects, ages, adversities and experimental paradigms are very heterogeneous [70] but most studies report a lower morning, flatter circadian cortisol rhythm [72] and down-regulation of the HPA axis also under stress conditions [73]. We should also consider children with prenatal alcohol exposure (PAE) because development of the HPA axis is shown to be influenced by PAE in animal models and human infants. If alcohol exposure is elevated (rank 4) children have cortisol levels that are significantly higher in the afternoon and at bedtime compared with control children or children with exposure to low or unknown levels of alcohol (alcohol exposure rank 3) [74]. These effects are long-term and could result in behavioural or emotional problems, vulnerability to mental health issues and diseases later in life [75]. Adopted children have a higher risk of ELA and have suffered from PAE more frequently than the general population. Significantly more elevated cortisol levels in the evening and flatter diurnal slopes were observed in children with both ELA and PAE than controls. It is likely that ELA and PAE negatively impact HPA development and functioning [75].

Some interesting studies have evaluated the potential for recovery of ELA damaged HPA, following improvements in care. Foster care or targeted interventions appear to be able to re-modulate HPA long-term [76]. The findings of DePasquale et al. offer initial evidence that post-adoption parental sensitivity may help promote internationally adopted children's stress-regulatory development following severe early life adversity. Postadoption parental sensitivity may be a vital resource through which internationally adopted children achieve positive developmental outcomes despite experiencing considerable early life adversity [77]. However, a recent study by Koss KJ et al. which examined changes in HPA in the two years after adoption, revealed persistently blunted HPA stress responses regardless of the child's age at adoption (before or after 2 years) [78].

\section{Conclusion}

In internationally adopted children disorders of linear growth, puberty development, thyroid function, and bone metabolism have been frequently reported. A careful auxological and endocrinological evaluation with follow-up is mandatory in these children. Paediatricians and other healthcare providers should be aware that auxological and endocrinological problems are common in newly arrived international adoptees and should tailor their approach to caring for these children accordingly.

\section{Acknowledgements}

Thanks to Tammy Ann Corkish BA MA for advice on the use of clear English.

Studies involving animals must include a statement on ethics approval Not applicable.

\section{Authors' contributions}

All authors participated in the drafting of the manuscript unanimously. All authors read and approved the final manuscript.

Funding

No external funding was provided for this study.

Availability of data and materials

Not applicable.

Ethics approval and consent to participate

Not applicable.

Consent for publication

Not applicable.

\section{Competing interests}

The authors have no conflicts of interest to declare.

\section{Author details}

${ }^{1}$ Health Sciences Department, University of Florence, Anna Meyer Children's University Hospital, Viale Pieraccini 24, 50139 Florence, Italy. ${ }^{2}$ Service

Universitaire de Pediatrie, UCAD, Dakar, Senegal.

Received: 23 February 2020 Accepted: 11 May 2020

Published online: 10 June 2020

References

1. United Nations. Department of Economic and Social Affairs. Population Division. Levels and Trends in Child Adoptions. In: Child Adoption: Trends and Policies, United Nations publications, 2009, page 66-87.

2. Italian Presidency of the Council of Ministers, Commission for International Adoptions. International adoptions. http://www.commissioneadozioni.it/it/ notizie/2016/dati-adozioni.aspx. Accessed June 2, 2016.

3. Hénaff F, Hazart I, Picherot G, Baqué F, Gras-Le Guen C, Launay E. Frequency and characteristics of infectious diseases in internationally adopted children: a retrospective study in Nantes from 2010 to 2012. J Travel Med. 2015;22: 179-85. https://doi.org/10.1111/jtm.12196.

4. Eckerle JK, Howard CR, John CC. Infections in internationally adopted children. Pediatr Clin N Am. 2013;60:487-505. https://doi.org/10.1016/j.pcl. 2012.12.010.

5. Sciauvaud J, Rigal E, Pascal J, Nourrisson C, Poirier P, Poirier V, et al. Transmission of infectious diseases from internationally adopted children to their adoptive families. Clin Microbiol Infect. 2014;20:746-51. https://doi.org/ 10.1111/1469-0691.12454.

6. van Schaik R, Wolfs TF, Geelen SP. Improved general health of international adoptees, but immunization status still insufficient. Eur J Pediatr. 2009;168: 1101-6. https://doi.org/10.1007/s00431-008-0895-7.

7. Martínez Ortiz A, Domínguez Pinilla N, Wudineh M, González-Granado LI. International adoption from Ethiopia in a 5-year period. An Pediatr (Barc). 2015;82:302-7. https://doi.org/10.1016/j.anpedi.2014.06.011.

8. Proos LA. Growth \& development of Indian children adopted in Sweden. Indian J Med Res. 2009:130:646-50.

9. A collaborative statement from Dietitians of Canada, Canadian Paediatric Society, The College of Family Physicians of Canada, and Community Health Nurses Association of Canada. Use of growth charts for assessing and monitoring growth in Canadian infants and children: Executive summary. Paediatr Child Health. 2004;9:171-84. 
10. Fuglestad AJ, Lehmann AE, Kroupina MG, Petryk A, Miller BS, Iverson SL, et al. Iron deficiency in international adoptees from Eastern Europe. J Pediatr. 2008;153:272-7. https://doi.org/10.1016/j.jpeds.2008.02.048.

11. Dalen $\mathrm{M}$, Theie $\mathrm{S}$. Internationally adopted children from non-European countries: general development during the first two years in the adoptive family. Sci World J. 2012;2012:375436. https://doi.org/10.1100/2012/375436.

12. Proos LA, Hofvander $Y$, Wennqvist $K$, Tuvemo T. A longitudinal study on anthropometric and clinical development of Indian children adopted in Sweden. I. Clinical and anthropometric condition at arrival. Ups J Med Sci. 1992:97:79-92.

13. Proos LA, Hofvander $Y$, Wennqvist $K$, Tuvemo T. A longitudinal study on anthropometric and clinical development of Indian children adopted in Sweden. II. Growth, morbidity and development during two years after arrival in Sweden. Ups J Med Sci. 1992;97:93-106.

14. Zhang $N$, Bécares $L$, Chandola $T$. Does the timing of parental migration matter for child growth? A life course study on left-behind children in rural China BMC Public Health. 2015;15:966. https://doi.org/10.1186/s12889-0152296-y.

15. Miller BS, Spratt EG, Himes JH, Condon D, Summer A, Papa CE, et al. Growth failure associated with early neglect: pilot comparison of neglected US children and international adoptees. J Pediatr Endocrinol Metab. 2015;28: 111-5. https://doi.org/10.1515/jpem-2014-0231.

16. Dieguez C, Page MD, Scanlon MF. Growth hormone neuroregulation and its alterations in disease states. Clin Endocrinol. 1988;28:109-43.

17. Miller BS, Kroupina MG, Mason P, Iverson SL, Narad C, Himes JH et al. Determinants of catch-up growth in international adoptees from eastern Europe. Int J Pediatr Endocrinol. 2010;2010:107252. doi: https://doi.org/10. 1155/2010/107252

18. Palacios J, Román M, Camacho C. Growth and development in internationally adopted children: extent and timing of recovery after early adversity. Child Care Health Dev. 2011;37:282-8. https://doi.org/10.1111/j. 1365-2214.2010.01142.x.

19. Kroupina MG, Eckerle JK, Fuglestad AJ, Toemen L, Moberg S, Himes JH et al. Associations between physical growth and general cognitive functioning in international adoptees from Eastern Europe at 30 months post-arrival. J Neurodev Disord. 2015;7:36. doi: https://doi.org/ 10.1186/s11689-015-9132-7.

20. Miller LC. Editorial commentary: international adoption: joys, challenges, and infectious diseases. Clin Infect Dis. 2008;47:815-7. https://doi.org/10.1086/ 591200.

21. Knuiman S, Rijk CH, Hoksbergen RA, van Baar AL. Children adopted from Poland display a high risk of foetal alcohol spectrum disorders and some may go undiagnosed. Acta Paediatr. 2015;104:206-11. https://doi.org/10. 1111/apa.12822.

22. Koren G. Adopted children from the former Soviet Union: are they at risk of fetal alcohol spectrum disorder? Can Fam Physician. 2013;59:1063-4.

23. Miller L, Chan W, Comfort K, Tirella L. Health of children adopted from Guatemala: comparison of orphanage and foster care. Pediatrics. 2005;115:e710-7.

24. Miller LC, Hendrie NW. Health of children adopted from China. Pediatrics. 2000;105:E76.

25. Hoyme HE, Kalberg WO, Elliott AJ, Blankenship J, Buckley D, Marais AS, et al. Updated clinical guidelines for diagnosing fetal alcohol spectrum disorders. Pediatrics. 2016;138:e20154256. https://doi.org/10.1542/peds.2015-4256.

26. Proos LA, Hofvander $Y$, Tuvemo T. Menarcheal age and growth pattern of Indian girls adopted in Sweden. I Menarcheal age Acta Paediatr Scand. 1991;80:852-8.

27. Proos LA, Hofvander $Y$, Tuvemo T. Menarcheal age and growth pattern of Indian girls adopted in Sweden. II. Catch-up growth and final height. Indian J Pediatr. 1991;58:105-14.

28. Miller LC, Kiernan MT, Mathers MI, Klein-Gitelman M. Developmental and nutritional status of internationally adopted children. Arch Pediatr Adolesc Med. 1995;149:40-4.

29. World Health Organization. WHO child growth standards: length/height-forage, weight-for-age, weight-for-length, weight-for-height and body mass index-for-age: methods and development. Geneva: World Health Organization; 2006.

30. Moon JS. Reappraisal of regional growth charts in the era of WHO growth standards. Pediatr Gastroenterol Hepatol Nutr. 2013;16:137-42. https://doi. org/10.5223/pghn.2013.16.3.137.

31. de Onis M, Onyango A, Borghi E, Siyam A, Blössner M, Lutter C. WHO multicentre growth reference study group. Worldwide implementation of the WHO child growth standards. Public Health Nutr. 2012;15:1603-10. https://doi.org/10.1017/\$136898001200105X

32. Gibelli D, De Angelis D, Cattaneo C. Radiological pitfalls of age estimation in adopted children: a case report. Minerva Pediatr. 2015;67:203-8.

33. Krstevska-Konstantinova M, Charlier C, Craen M, Du Caju M, Heinrichs C, de Beaufort $C$, et al. Sexual precocity after immigration from developing countries to Belgium: evidence of previous exposure to organochlorine pesticides. Hum Reprod. 2001;16:1020-6.

34. Shah S, Jeong KS, Park H, Hong YC, Kim Y, Kim B, et al. Environmental pollutants affecting children's growth and development: collective results from the MOCEH study, a multi-centric prospective birth cohort in Korea. Environ Int. 2020;137:105547. https://doi.org/10.1016/j.envint.2020.105547.

35. Reid BM, Miller BS, Dorn LD, Desjardins C, Donzella B, Gunnar M. Earlygrowth faltering in post-institutionalized youth and later anthropometric and pubertal development. Pediatr Res. 2017:82:278-84.

36. Adolfsson S, Westphal O. Early pubertal development in girls adopted from far-eastern countries. Pediatr Res .1981;15:82. doi:https://doi.org/10.1203/ 00006450-198101000-00068.

37. Kempers MJ, Otten BJ. Idiopathic precocious puberty versus puberty in adopted children; auxological response to gonadotrophin-releasing hormone agonist treatment and final height. Eur J Endocrinol. 2002;147: 609-16.

38. Baron S, Battin J, David A, Limal JM. Precocious puberty in children adopted from foreign countries. Arch Pediatr. 2000;7:809-16.

39. Teilmann G, Pedersen CB, Skakkebaek NE, Jensen TK. Increased risk of precocious puberty in internationally adopted children in Denmark. Pediatrics. 2006;118:e391-9.

40. Hayes P, Tan TX. Timing of menarche in girls adopted from China: a cohort study. Child Care Health Dev. 2016;42:859-62. https://doi.org/10.1111/cch. 12393.

41. Proos L, Gustafsson J. Is early puberty triggered by catch-up growth following undernutrition? Int J Environ Res Public Health. 2012;9:1791-809.

42. Parent AS, Teilmann G, Juul A, Skakkebaek NE, Toppari J, Bourguignon JP. The timing of normal puberty and the age limits of sexual precocity: variations around the world, secular trends, and changes after migration. Endocr Rev. 2003:24:668-93.

43. Hayes P. International adoption, "early" puberty, and underrecorded age. Pediatrics. 2013:131:1029-31.

44. Mul D, Oostdijk W, Drop SL. Early puberty in adopted children. Horm Res. 2002;57:1-9.

45. Virdis R, Street ME, Zampolli M, Radetti G, Pezzini B, Benelli M, et al. Precocious puberty in girls adopted from developing countries. Arch Dis Child. 1998;78:152-4.

46. Pucarelli I, Segni M, Ortore M, Moretti A, lannaccone R, Pasquino AM. Combined therapy with GnRH analog plus growth hormone in central precocious puberty. J Pediatr Endocrinol Metab. 2000;13(Suppl 1):811-20.

47. Mul D, Oostdijk W, Waelkens JJ, Drop SL. Final height after treatment of early puberty in short adopted girls with gonadotrophin releasing hormone agonist with or without growth hormone. Clin Endocrinol (Oxf). 2005;63:185-90.

48. de Escobar GM, Obregón MJ, del Rey FE. lodine deficiency and brain development in the first half of pregnancy. Public Health Nutr. 2007;10: 1554-70. https://doi.org/10.1017/\$1368980007360928.

49. World Health Organization/International Council for the Control of the lodine Deficiency Disorders/United Nations Childrens Fund (WHO/ICCIDD/ UNICEF). Assessment of the iodine deficiency disorders and monitoring their elimination. Geneva: World Health Organization, 2007.

50. Chung HR. lodine and thyroid function. Ann Pediatr Endocrinol Metab. 2014;19:8-12.

51. Therrell BL, Padilla CD, Loeber JG, Kneisser I, Saadallah A, Borrajo GJ, Adams J. Current status of newborn screening worldwide: 2015. Semin Perinatol. 2015;39:171-87. https://doi.org/10.1053/j.semperi.2015.03.002.

52. Delange F, Thilly C, Bourdoux P, Hennart P, Courtois P, Ermans AM. 1982. Influence of dietary goitrogens during pregnancy in humans on thyroid function of the newborn. In nutritional factors involved in the goitrogenic action of cassava. F. Delange, F.B. Iteke, and a.M. Ermans, editors. Ottawa: International Development Research Centre publ. 40-50.

53. Vanderpas J, Bourdoux P, Lagasse R, Rivera M, Dramaix M, Lody D, Nelson G, Delange F, Ermans AM, Thilly $\mathrm{CH}$. Endemic infantile hypothyroidism in a severe endemic goitre area of Central Africa. Clin Endocrinol. 1984;20:327-40.

54. Kochupillai N, Pandav CS. 1987. Neonatal chemical hypothyroidism in iodine-deficient environments. In the prevention and control of iodine 
deficiency disorders. B.S. Hetzel, J.T. Dunn, and J.B. Stanbury, editors. Amsterdam:Elsevier publ. 85-93.

55. Kapil U, Singh P, Pathak P, Singh C. Assessment of iodine deficiency disorders in district Bharatpur, Rajasthan. Indian Pediatr. 2003;40:147-9.

56. Crocombe $\mathrm{S}$, Mughal MZ, Berry JL. Symptomatic vitamin D deficiency among non-Caucasian adolescents living in the United Kingdom. Arch Dis Child. 2004;89:197-9.

57. El-Hajj Fuleihan G, Nabulsi M, Choucair M, Salamoun M, Hajj Shahine C, Kizirian A, Tannous R. Hypovitaminosis D in healthy schoolchildren. Pediatrics. 2001;107:E53.

58. Dahifar H, Faraji A, Ghorbani A, Yassobi S. Impact of dietary and lifestyle on vitamin D in healthy student girls aged 11-15 years. J Med Investig. 2006;53:204-8.

59. Bhattacharyya AK. Nutritional rickets in the tropics. World Rev Nutr Diet. 1992;67:140-97.

60. Agarwal A, Gupta SK, Sukumar R. Hyperparathyroidism and malnutrition with severe vitamin D deficiency. World J Surg. 2009;33:2303-13. https://doi. org/10.1007/s00268-009-0044-0

61. Miller LC. Rickets. In: The Handbook of International Adoption Medicine: A Guide for Physicians, Parents, and Providers. Oxford University Press, USA, 2005, pp 325-331.

62. Reeves GD, Bachrach S, Carpenter TO, Mackenzie WG. Vitamin D-deficiency rickets in adopted children from the former Soviet Union: an uncommon problem with unusual clinical and biochemical features. Pediatrics. 2000;106:1484-8.

63. Benoit TC, Jocelyn LJ, Moddemann DM, Embree JE. Romanian adoption. The Manitoba experience Arch Pediatr Adolesc Med. 1996;150:1278-82.

64. Valentini P, Gargiullo L, Ceccarelli M, et al. Health status of internationally adopted children. The experience of an Italian "GLNBI" paediatric Centre. Italian J Public Health. 2012;9:e7527-32.

65. Capelli A, A. Urbino et al. Rischio di rachitismo nel bambino immigrato e necessità di profilassi con vitamina D. Atti $64^{\circ}$ Congresso Nazionale SIP Genova 2008.

66. Guala A, Guarino R, Ghiotti P, et al. II rachitismo in Piemonte. Una sorveglianza attraverso gli ospedali Medico e Bambino. 2006;11:119.

67. Gustafson KL1, Eckerle JK, Howard CR, Andrews B, Polgreen LE. Prevalence of vitamin $D$ deficiency in international adoptees within the first 6 months after adoption. Clin Pediatr (Phila) 2013; 52: 1149-1153. doi: https://doi.org/ 10.1177/0009922813495955.

68. Chiappini E, Vierucci F, Ghetti F, de Martino M, Galli L. Vitamin D status and predictors of Hypovitaminosis $D$ in internationally adopted children. PLoS One. 2016;11:e0158469. https://doi.org/10.1371/journal.pone.0158469).

69. Salerno G, Ceccarelli M, de Waure C, D'Andrea M, Buonsenso D, Faccia V, Pata D, Valentini P. Epidemiology and risk factors of hypovitaminosis D in a cohort of internationally adopted children: a retrospective study. Ital J Pediatr. 2018;44(1):86. https://doi.org/10.1186/s13052-018-0527-4.

70. Hunter AL, Minnis H, Wilson P. Altered stress responses in children exposed to early adversity: a systematic review of salivary cortisol studies. Stress. 2011;14:614-26.

71. Danese A, McEwen BS. Adverse childhood experiences, allostasis, allostatic load, and age-related disease. Physiol Behav. 2012;106:29-39.

72. Strüber N, Strüber D, Roth G. Impact of early adversity on glucocorticoid regulation and later mental disorders. Neurosci Biobehav Rev. 2014;38:17-37.

73. Koss K, Mliner SB, Donzella B, Gunnar MR. Early adversity, hypocortisolism, and behavior problems at school entry: a study of internationally adopted children. Psychoneuroendocrinology. 2016;66:31-8.

74. McLachlan K, Rasmussen C, Oberlander TF, Loock C, Pei J, Andrew G, Reynolds J, Weinberg J. Dysregulation of the cortisol diurnal rhythm following prenatal alcohol exposure and early life adversity. Alcohol. 2016; 53:9-18. https://doi.org/10.1016/j.alcohol.2016.03.003.

75. Keiver K, Bertram CP, Orr AP, Clarren S. Salivary cortisol levels are elevated in the afternoon and at bedtime in children with prenatal alcohol exposure. Alcohol. 2015;49:79-87.

76. Slopen N, McLaughlin KA, Shonkoff JP. Interventions to improve cortisol regulation in children: a systematic review. Pediatrics. 2014;133:312-26.

77. DePasquale CE, Raby KL, Hoye J, Dozier M. Parenting predicts strange situation cortisol reactivity among children adopted internationally. Psychoneuroendocrinology. 2018 Mar;89:86-91. https://doi.org/10.1016/j. psyneuen.2018.01.003.

78. Koss KJ, Mliner SB, Donzella B, Gunnar MR. Early adversity, hypocortisolism, and behavior problems at school entry: a study of internationally adopted children. Psychoneuroendocrinology. 2016;66:31-8. https://doi.org/10.1016/j. psyneuen.2015.12.018

\section{Publisher's Note}

Springer Nature remains neutral with regard to jurisdictional claims in published maps and institutional affiliations.

\section{Ready to submit your research? Choose BMC and benefit from:}

- fast, convenient online submission

- thorough peer review by experienced researchers in your field

- rapid publication on acceptance

- support for research data, including large and complex data types

- gold Open Access which fosters wider collaboration and increased citations

- maximum visibility for your research: over $100 \mathrm{M}$ website views per year

At BMC, research is always in progress.

Learn more biomedcentral.com/submissions 